\title{
Bcl6 and Blimp-1 Are Reciprocal and Antagonistic Regulators of T Follicular Helper Cell Differentiation
}

\author{
Robert J. Johnston ${ }^{1,2,{ }^{*}, \text { Amanda C. Poholek }}{ }^{3,{ }^{*}, \text { Daniel DiToro }}{ }^{1}$, Isharat Yusuf ${ }^{1}$, Danelle \\ Eto $^{1}$, Burton Barnett ${ }^{1}$, Alexander L. Dent ${ }^{4}$, Joe Craft ${ }^{5,6}$, and Shane Crotty ${ }^{1,2, \dagger}$ \\ ${ }^{1}$ Division of Vaccine Discovery, La Jolla Institute for Allergy and Immunology (LIAI), 9420 Athena \\ Circle, La Jolla, CA 92037, USA. \\ ${ }^{2}$ Department of Medicine, University of California, San Diego School of Medicine, La Jolla, CA \\ 92037, USA. \\ ${ }^{3}$ Department of Cell Biology, Yale University School of Medicine, New Haven, CT 06520, USA. \\ ${ }^{4}$ Department of Microbiology and Immunology and Walther Oncology Center, Indiana University \\ School of Medicine, Indianapolis, IN 46202, USA. \\ ${ }^{5}$ Department of Immunobiology, Yale University School of Medicine, New Haven, CT 06520, USA. \\ ${ }^{6}$ Section of Rheumatology, Department of Internal Medicine, Yale School of Medicine, New Haven, \\ CT 06520, USA.
}

\begin{abstract}
Effective B cell-mediated immunity and antibody responses often require help from $\mathrm{CD}^{+} \mathrm{T}$ cells. It is thought that a distinct $\mathrm{CD} 4^{+}$effector $\mathrm{T}$ cell subset, called $\mathrm{T}$ follicular helper cells $\left(\mathrm{T}_{\mathrm{FH}}\right)$, provides this help; however, the molecular requirements for $\mathrm{T}_{\mathrm{FH}}$ differentiation are unknown. We found that expression of the transcription factor $\mathrm{Bcl} 6$ in $\mathrm{CD}^{+} \mathrm{T}$ cells is both necessary and sufficient for in vivo $\mathrm{T}_{\mathrm{FH}}$ differentiation and $\mathrm{T}$ cell help to $\mathrm{B}$ cells in mice. In contrast, the transcription factor Blimp-1, an antagonist of $\mathrm{Bcl}$, inhibits $\mathrm{T}_{\mathrm{FH}}$ differentiation and help, thereby preventing $\mathrm{B}$ cell germinal center and antibody responses. These findings demonstrate that $\mathrm{T}_{\mathrm{FH}}$ cells are required for proper $\mathrm{B}$ cell responses in vivo and that $\mathrm{Bcl} 6$ and Blimp-1 play central but opposing roles in $\mathrm{T}_{\mathrm{FH}}$ differentiation.
\end{abstract}

Each lineage of effector $\mathrm{CD}^{+} \mathrm{T}$ cells $\left(\mathrm{T}_{\mathrm{H}} 1, \mathrm{~T}_{\mathrm{H}} 2, \mathrm{~T}_{\mathrm{H}} 17\right.$, and $\left.\mathrm{T}_{\text {reg }}\right)$ is defined and controlled by a unique master regulator transcription factor (T-bet, GATA3, ROR $\gamma$ t, and Foxp3, respectively) (1). A proposed fifth effector subset, $\mathrm{T}$ follicular helper $\left(\mathrm{T}_{\mathrm{FH}}\right)$ cells, is thought to provide help for the generation of B cell-mediated immune responses, including class switch recombination, germinal center differentiation, and affinity maturation (2). Here, we identified $\mathrm{Bcl} 6$ as a $\mathrm{T}_{\mathrm{FH}}$ master regulator and found that germinal center formation does not occur in the absence of $\mathrm{T}_{\mathrm{FH}}$ cells.

Copyright 2009 by the American Association for the Advancement of Science; all rights reserved.

†To whom correspondence should be addressed. shane@liai.org.

*These authors contributed equally to this work.

Supporting Online Material

www.sciencemag.org/cgi/content/full/1175870/DC1

Methods

Table S1

Figs. S1 to S14

References 
$\mathrm{T}_{\mathrm{FH}}$ cells are well described phenotypically in humans, and more recently in mice, as expressing high levels of the chemokine receptor CXCR5 and molecules such as ICOS, PD1, interleukin-21 (IL-21), and BTLA (2-9). Given that CD4 ${ }^{+} \mathrm{T}$ cells can up-regulate CXCR5 and/or ICOS after activation $(2,10)$, it is important to phenotypically distinguish $\mathrm{T}_{\mathrm{FH}}$ from highly activated $\mathrm{CD} 4^{+} \mathrm{T}$ cells. We identified $\mathrm{T}_{\mathrm{FH}}$ cells in mice in the context of acute infection with lymphocytic choriomeningitis virus (LCMV) by adoptively transferring T cell receptor (TCR) transgenic T cells specific for the LCMV epitope gp66-77 in the context of major histocompatibility complex (MHC) class II molecule I-A ${ }^{\mathrm{b}}$ (SMtg). $\mathrm{T}_{\mathrm{FH}}$ cells were

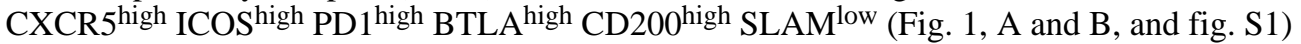
and capable of producing IL-21 (Fig. 1C). We confirmed these results for polyclonal LCMVspecific CD4 ${ }^{+} \mathrm{T}$ cell responses (fig. S2). CXCR5 is the receptor for the B cell follicle chemokine CXCL13 (11), and $\mathrm{T}_{\mathrm{FH}}$ cells were selectively able to migrate in response to CXCL13 in vitro (Fig. 1D), consistent with the importance of CXCR5 for $\mathrm{T}_{\mathrm{FH}}(6,12)$.

To understand how $\mathrm{T}_{\mathrm{FH}}$ differentiation is transcriptionally regulated, we performed gene expression microarray analysis of virus-specific $\mathrm{T}_{\mathrm{FH}}$ and non- $\mathrm{T}_{\mathrm{FH}}$ effector $\mathrm{CD} 4^{+} \mathrm{T}$ cells (Fig. $1 \mathrm{E}$ and figs. S3 and S4). Notably, the transcription factor B cell CLL/lymphoma 6 (Bcl6) was strongly up-regulated in $\mathrm{T}_{\mathrm{FH}}$ (Fig. 1E). This is in agreement with previous reports of elevated Bcl6 expression in murine and human $\mathrm{T}_{\mathrm{FH}}$ cells $(3-5,8)$. Furthermore, Blimp-1 ( $\mathrm{prdm} /$ ) was the most down-regulated transcription factor in $\mathrm{T}_{\mathrm{FH}}$ cells (fig. S4), consistent with a recent report (13). Bcl6 is essential for germinal center B cell differentiation (14-16), and Blimp-1 is well characterized as an antagonist of Bcl6 that can also be directly repressed by Bcl6 (1620). Up-regulation of Bcl6 mRNA (Fig. 1F) and down-regulation of Blimp-1 mRNA (Fig. 1G) were confirmed by quantitative polymerase chain reaction (qPCR). Bcl6 protein expression was detected in germinal center $\mathrm{CD} 4^{+} \mathrm{T}$ cells (fig. S2), consistent with previous observations in human lymphoid tissue $(4,21)$.

Although Bcl6 mRNA expression has been correlated with $\mathrm{T}_{\mathrm{FH}}$, no experimental data supporting a specific role for Bcl6 in $\mathrm{T}_{\mathrm{FH}}$ differentiation have been reported. We expressed Bcl6 in SMtg CD4 ${ }^{+} \mathrm{T}$ cells via a retroviral vector $(\mathrm{RV})$ with a bicistronic mRNA coexpressing green fluorescent protein (GFP) (fig. S5). Transduced Bc16-RV ${ }^{+}$SMtg and control untransduced SMtg CD4 ${ }^{+} \mathrm{T}$ cells were transferred into naïve C57BL/6 hosts, which were subsequently infected with LCMV, and $\mathrm{T}_{\mathrm{FH}}$ differentiation was examined (Fig. 2, A to E). Bcl6 expression drove nearly absolute $\mathrm{T}_{\mathrm{FH}}$ differentiation in vivo (80 to 90\%; Fig. 2, B and $\mathrm{C}$ ), in contrast to $\mathrm{T}_{\mathrm{FH}}$ differentiation in control untransduced (GFP-) SMtg cells in the same mice (Fig. 2B) or mice that received SMtg transduced with a control retrovirus expressing only GFP $\left(\mathrm{GFP}-\mathrm{RV}^{+}\right)$and untransduced SMtg in equal proportions (Fig. 2C). Comparably striking results were seen in studies where only Bcl6-RV $\mathrm{RV}^{+}$or GFP-RV ${ }^{+} \mathrm{SMtg} \mathrm{CD} 4^{+} \mathrm{T}$ cells were transferred into host mice (fig. S6). Bcl6 overexpression did not affect $\mathrm{T}$ cell expansion in vivo (fig. S5). Constitutive expression of Bcl6 drove up-regulation of CXCR5, PD-1, ICOS, CD200, and BTLA expression (Fig. 2, D and E, and fig. S6), as well as the inhibition of SLAM and Blimp-1 (fig. S6; see below). These results indicate that Bcl6 expression drives full $\mathrm{T}_{\mathrm{FH}}$ differentiation in vivo.

$\mathrm{T}_{\mathrm{FH}}$ differentiation is known to require the presence of $\mathrm{B}$ cells and is thought to require the presence of antigen-specific B cells (6). We thus hypothesized that Bcl6 expression induced by interaction with antigen-specific $\mathrm{B}$ cells could be the event that commits a $\mathrm{T}$ cell to $\mathrm{T}_{\mathrm{FH}}$ differentiation. To test this, we examined whether Bcl6 expression in $\mathrm{CD}^{+} \mathrm{T}$ cells was sufficient to drive $\mathrm{T}_{\mathrm{FH}}$ differentiation in $\mu \mathrm{MT} \mathrm{B}$ cell-deficient mice and in $\mathrm{B}$ cell receptor (BCR) transgenic mice of an irrelevant specificity (MD4, specific for hen egg lysozyme). GFP$\mathrm{RV}^{+} \mathrm{SMtg} \mathrm{CD}^{+} \mathrm{T}$ cells failed to differentiate into $\mathrm{T}_{\mathrm{FH}}$ in $\mu \mathrm{MT}$ or MD4 mice infected with LCMV (Fig. 2, F and G), which demonstrates that $\mathrm{T}_{\mathrm{FH}}$ differentiation in the context of a viral infection is dependent on the presence of antigen-specific B cells. In contrast, Bcl6-RV ${ }^{+} \mathrm{SMtg}$ 
cells differentiated into $\mathrm{T}_{\mathrm{FH}}$ in the absence of antigen-specific $\mathrm{B}$ cells or even in the total absence of B cells (Fig. 2, F and G). These results indicate that cognate T-B interactions induce Bcl6 expression in $\mathrm{CD}^{+} \mathrm{T}$ cells and that $\mathrm{Bcl} 6$ is sufficient to drive $\mathrm{T}_{\mathrm{FH}}$ differentiation, even in the absence of such interactions.

$\mathrm{T}_{\mathrm{FH}}$ cells are thought to provide $\mathrm{B}$ cell help in vivo $(2,22)$. We assessed the capacity of Bcl6$\mathrm{RV}^{+} \mathrm{SMtg} \mathrm{CD}^{+} \mathrm{T}$ cells to help $\mathrm{B}$ cells in vivo by examining germinal center development in LCMV-infected mice. Overexpression of Bcl6 increased the already robust frequency of germinal center B cells after LCMV infection (Fig. 3, A and B). As an additional measure of $\mathrm{B}$ cell help, we also examined the role of Bcl6 in T cell-dependent antibody production. Constitutive expression of Bcl6 in OT-II CD4 ${ }^{+} \mathrm{T}$ cells enhanced NP-Ova serum immunoglobulin $\mathrm{G}$ (IgG) responses (Fig. 3C and fig. S7), which were sustained (Fig. 3C). Our results suggest that $\mathrm{Bcl} 6$ was specifically enhancing $\mathrm{T}_{\mathrm{FH}}$ differentiation and not skewing the $\mathrm{T}_{\mathrm{H}} 1 / \mathrm{T}_{\mathrm{H}} 2$ profile of the $\mathrm{CD} 4^{+} \mathrm{T}$ cells, because all IgG isotypes were enhanced in the mice receiving Bcl6-expressing OT-II CD4 ${ }^{+} \mathrm{T}$ cells, with the strong IgG1 dominance maintained (fig. S7).

The results of these experiments showed that Bcl6 expression was sufficient to drive the differentiation of functional $\mathrm{T}_{\mathrm{FH}}$. To test whether $\mathrm{Bcl} 6$ was also necessary for $\mathrm{T}_{\mathrm{FH}}$ differentiation, we examined $\mathrm{Bcl6}^{-1-} \mathrm{CD} 4^{+} \mathrm{T}$ cells. $\mathrm{Bcl6}^{-{ }_{-}}$mice have an abundance of highly activated $\mathrm{CD} 4^{+} \mathrm{T}$ cells (fig. S8) and succumb to early mortality $(14,15)$. To circumvent these issues, we transferred $\mathrm{Bcl6}^{+/+}$or $\mathrm{Bcl6}^{-/-}$OT-II bone marrow into irradiated C57BL/6 recipients (fig. S8). $B c l 6^{-1-}$ OT-II CD4 ${ }^{+}$T cells obtained from chimeric mice did not exhibit lymphoproliferation or spontaneous activation upon transfer into C57BL/6 mice (fig. S8, D to F). $\mathrm{Bcl6}^{-/-}$or $\mathrm{Bcl6}^{+/+}$OT-II recipient mice were subsequently immunized with Ova in alum. Strikingly, Bcl6 $^{-/-}$OT-II CD4 ${ }^{+}$T cells did not differentiate into $\mathrm{T}_{\mathrm{FH}}$ cells (Fig. 3D). We hypothesized that if $\mathrm{T}_{\mathrm{FH}}$ cells are necessary for $\mathrm{B}$ cell help in vivo, a cell-intrinsic $\mathrm{CD} 4^{+} \mathrm{T}$ cell block in $\mathrm{T}_{\mathrm{FH}}$ differentiation should result in a failure to generate antigen-specific $\mathrm{B}$ cell responses such as germinal center formation. To test this hypothesis, we transferred $\mathrm{Bcl}^{-/-}$or $\mathrm{Bcl6}^{+/+}$OT-II CD4 ${ }^{+} \mathrm{T}$ cells into $\mathrm{Icos}^{-/-}$mice, which have ineffective B cell help $(2,23)$. After NP-Ova immunization, $\mathrm{ICos}^{-1-}$ mice that received $\mathrm{Bcl6}^{-{ }_{-}} \mathrm{OT}-\mathrm{II} \mathrm{CD} 4^{+} \mathrm{T}$ cells were unable to form germinal centers, in contrast to mice that received wild-type OT-II CD4 ${ }^{+} \mathrm{T}$ cells (Fig. 3, $\mathrm{E}$ to $\mathrm{G}$, and fig. S9). These data demonstrate that $\mathrm{Bcl} 6$ is necessary for $\mathrm{T}_{\mathrm{FH}}$ differentiation and that $\mathrm{T}_{\mathrm{FH}}$ cells are necessary for germinal center formation. Together, these results indicate that $\mathrm{Bcl6}$ is a bona fide master regulator of $\mathrm{T}_{\mathrm{FH}}$ differentiation in vivo.

Blimp-1 is a known antagonist of Bcl6, capable of directly inhibiting Bcl6 expression in B and T cells $(17,18)$. Conversely, Blimp-1 expression can be inhibited by Bcl6 $(16-18,20)$. On the basis of our observations that Bcl6 drives $\mathrm{T}_{\mathrm{FH}}$ cell differentiation and function, and because Blimp-1 was the single most down-regulated transcription factor in $\mathrm{T}_{\mathrm{FH}}$ cells by gene expression array analysis (Fig. 1E and fig. S4) and qPCR (Fig. 1G), we hypothesized a role for Blimp-1 in blocking $\mathrm{T}_{\mathrm{FH}}$ differentiation in vivo. We constructed a Blimp-1 retroviral expression vector, Blimp1-RV (fig. S5), designed to express physiological levels of Blimp-1. Only CD $4^{+} \mathrm{T}$ cells expressing low levels of the GFP reporter were used for in vivo experiments (fig. S10A). Blimp-1 blocked Bcl6 protein expression in activated antigen-specific $\mathrm{CD} 4^{+} \mathrm{T}$ cells in vivo (Fig. 4A). To determine the effects of Blimp-1 on $\mathrm{T}_{\mathrm{FH}}$ differentiation, we mixed Blimp1-RV ${ }^{+}$SMtg $\mathrm{CD} 4^{+} \mathrm{T}$ cells and untransduced control SMtg cells in equal proportions and transferred them into host mice subsequently infected with LCMV. We observed normal proliferation of Blimp-1-expressing SMtg $\mathrm{CD} 4^{+} \mathrm{T}$ cells (fig. S10); however, $\mathrm{T}_{\mathrm{FH}}$ differentiation was severely abrogated, with an $80 \%$ reduction in $\mathrm{T}_{\mathrm{FH}}$ frequency (Fig. 4, B and C). Blockade of $\mathrm{T}_{\mathrm{FH}}$ differentiation by Blimp-1 was also observed when mice separately received Blimp1-RV ${ }^{+}$versus GFP- $\mathrm{RV}^{+} \mathrm{SMtg}$ cells (fig. S10, F and G). Constitutive expression of Blimp-1 inhibited acquisition of the $\mathrm{T}_{\mathrm{FH}}$ phenotype: SLAM expression was increased (Fig. 
4D), whereas CXCR5, ICOS, and PD-1 expression were all decreased (Fig. 4D and fig. S10). Inhibition of $\mathrm{T}_{\mathrm{FH}}$ differentiation by Blimp-1 was physiological and specific, because the expression levels of SLAM, ICOS, and PD-1 by Blimp1-RV ${ }^{+}$SMtg CD4 ${ }^{+} \mathrm{T}$ cells were equivalent to the expression levels seen in wild-type activated non- $\mathrm{T}_{\mathrm{FH}} \mathrm{SMtg} \mathrm{CD} 4{ }^{+} \mathrm{T}$ cells, and not naïve cells (fig. S10I). Blimp1-RV ${ }^{+}$and wild-type non- $\mathrm{T}_{\mathrm{FH}} \mathrm{SMtg}$ cells also expressed comparable amounts of the cytokines interferon- $\gamma$ (IFN- $\gamma$ ) and IL-2 (fig. S11). High amounts of Blimp-1 expression can inhibit proliferation in B and T cells $(17,24,25)$. The moderate level of Blimp-1 expression used in our experiments (fig. S10E) did not affect proliferation in vivo (fig. S10, C, D, and H), in agreement with previous in vitro studies (26) and our observation that non- $\mathrm{T}_{\mathrm{FH}} \mathrm{CD} 4^{+} \mathrm{T}$ cells express 20 times as much Blimp-1 as do $\mathrm{T}_{\mathrm{FH}}$ cells and are still proliferative. Blimp-1 expression did not affect expression of the $\mathrm{T}$ helper lineage-specific transcription factors Foxp3, GATA3, and ROR $\gamma \mathrm{t}$ (fig. S11), which indicates that Blimp-1 did not induce differentiation into other helper lineages. Collectively, these data suggest that Blimp-1 acts specifically to repress Bcl6 and thus blocks $\mathrm{T}_{\mathrm{FH}}$ differentiation.

Given that Blimp-1 is a physiological inhibitor of Bcl6 expression and $\mathrm{T}_{\mathrm{FH}}$ differentiation in vivo, we performed an additional test of the necessity of $\mathrm{T}_{\mathrm{FH}}$ for $\mathrm{B}$ cell help by transferring Blimp1-RV ${ }^{+}$OT-II and GFP-RV ${ }^{+}$OT-II CD4 ${ }^{+} \mathrm{T}$ cells into SAP-deficient $\left(s h 2 d l a^{-1-}\right)$ mice [SAP-deficient mice exhibit a CD4 ${ }^{+} \mathrm{T}$ cell-intrinsic defect in germinal center formation (2729)] subsequently immunized with NP-Ova. We observed germinal centers and anti-NP-Ova serum IgG in GFP-RV ${ }^{+}$OT-II CD4 ${ }^{+} \mathrm{T}$ cell recipient mice after immunization (Fig. 4, E and F). Strikingly, although OT-II cell numbers were normal in Blimp1-RV ${ }^{+}$OT-II recipient mice (fig. S12), germinal centers were reduced by $90 \%$ (Fig. 4E). Constitutive Blimp-1 expression also inhibited the NP-Ova-specific IgG response, reducing the serum antibody concentration to only $16 \%$ of normal levels (Fig. 4F). All IgG isotypes were reduced (fig. S12), confirming that Blimp-1 was specifically inhibiting $\mathrm{T}_{\mathrm{FH}}$ differentiation. These results demonstrate both that Blimp-1 inhibits $\mathrm{CD} 4^{+} \mathrm{T}$ cell help to $\mathrm{B}$ cells and that $\mathrm{T}_{\mathrm{FH}}$ cells are required for $\mathrm{B}$ cell help in vivo.

To confirm the biological role of Blimp-1 in inhibiting $\mathrm{T}_{\mathrm{FH}}$ differentiation in vivo, we tested the ability of Blimp-1-deficient $\mathrm{CD} 4^{+} \mathrm{T}$ cells to differentiate into $\mathrm{T}_{\mathrm{FH}}$. To avoid autoimmunity complications $(30,31)$, we deleted Blimp-1 (prdml) in vitro in mature prdm $I^{f l f l} \mathrm{CD}^{+} \mathrm{T}$ cells (32) by means of a Cre-expressing RV. We transferred $\mathrm{Cre}^{+} \mathrm{SMtg}^{+}$prdm ${ }^{f l / f l}$ and control $\mathrm{Cre}^{-} \mathrm{SMtg}^{+}$prdm I ${ }^{f l f l} \mathrm{CD}^{+} \mathrm{T}$ cells into mice subsequently infected with LCMV. Deletion of prdml substantially enhanced $\mathrm{T}_{\mathrm{FH}}$ differentiation in vivo (Fig. $4 \mathrm{G}$ ) without altering proliferation (fig. S13). These data indicate that Blimp-1 expression in vivo normally restricts Bcl6 expression and $\mathrm{T}_{\mathrm{FH}}$ differentiation. In sum, our results reveal that Bcl6 and Blimp-1 are reciprocal master regulators of $\mathrm{T}_{\mathrm{FH}}$ differentiation, with $\mathrm{T}_{\mathrm{FH}}$ differentiation in vivo requiring the presence of Bcl6 and the absence of Blimp-1.

There has been extensive speculation about a role for Bcl6 in $\mathrm{T}_{\mathrm{FH}}$ differentiation, based on gene expression data from human $(2,4)$ and murine $\mathrm{T}_{\mathrm{FH}}$ studies $(3,8,9,13)$. Our data directly show that $\mathrm{Bcl} 6$ specifically drives $\mathrm{T}_{\mathrm{FH}}$ differentiation and is a bona fide master regulator. The relationship between $\mathrm{T}_{\mathrm{FH}}$ and other $\mathrm{CD} 4^{+} \mathrm{T}$ cell lineages has been a long-standing problem. The predominant $\mathrm{CD}^{+} \mathrm{T}$ cell response to LCMV is $\mathrm{T}_{\mathrm{H}} 1$ (fig. $\mathrm{S} 14$ ), and it is notable that $\mathrm{T}$ bet and IFN- $\gamma$ were still expressed in the $\mathrm{T}_{\mathrm{FH}}$ in vivo, although at lower levels than in $\mathrm{T}_{\mathrm{H}} 1 /$ non- $\mathrm{T}_{\mathrm{FH}} \mathrm{LCMV}$-specific CD4 ${ }^{+} \mathrm{T}$ cells (fig. S14). These observations are consistent with a model in which $\mathrm{T}_{\mathrm{FH}}$ cells follow their own differentiation pathway but are not an isolated lineage and can exhibit partial characteristics of $\mathrm{T}_{\mathrm{H}} 1 / \mathrm{T}_{\mathrm{H}} 2$ polarization depending on environmental conditions. This overlapping differentiation model would resolve the conundrum in the literature that neither $\mathrm{T}_{\mathrm{H}} 1, \mathrm{~T}_{\mathrm{H}} 2$, nor $\mathrm{T}_{\mathrm{H}} 17$ are required for $\mathrm{B}$ cell help in vivo $(8,33,34)$, but that cells with $\mathrm{T}_{\mathrm{H}} 1, \mathrm{~T}_{\mathrm{H}} 2$, or $\mathrm{T}_{\mathrm{H}} 17$ phenotypes can provide $\mathrm{B}$ cell help in vivo $(9,35-39)$. 
The capacity for $\mathrm{B}$ cell help is a central attribute of $\mathrm{CD} 4^{+} \mathrm{T}$ cells and is a cornerstone of protective immunity. It is well known that in B cells, Bcl6 and Blimp-1 are powerful antagonistic master regulators of germinal center $\mathrm{B}$ cell differentiation and plasma cell differentiation. Our findings that Bcl6 and Blimp-1 also control $\mathrm{T}_{\mathrm{FH}}$ differentiation illustrate the elegant use of the same antagonistic transcription factors to drive different functions in two lymphocyte populations differentiating in parallel: antigen-specific $\mathrm{B}$ cells and the $\mathrm{T}_{\mathrm{FH}}$ cells that provide their help. Manipulation of these signaling pathways in vivo may have substantial therapeutic benefit for enhancing vaccines or, conversely, blocking auto-antibody responses.

\section{Supplementary Material}

Refer to Web version on PubMed Central for supplementary material.

\section{References and Notes}

1. Zhu J, Paul WE. Blood 2008;112:1557. [PubMed: 18725574]

2. King C, Tangye S, Mackay C. Annu. Rev. Immunol 2008;26:741. [PubMed: 18173374]

3. Vinuesa CG, et al. Nature 2005;435:452. [PubMed: 15917799]

4. Chtanova T, et al. J. Immunol 2004;173:68. [PubMed: 15210760]

5. Rasheed AU, Rahn HP, Sallusto F, Lipp M, Müller G. Eur. J. Immunol 2006;36:1892. [PubMed: 16791882]

6. Haynes NM, et al. J. Immunol 2007;179:5099. [PubMed: 17911595]

7. Vogelzang A, et al. Immunity 2008;29:127. [PubMed: 18602282]

8. Nurieva RI, et al. Immunity 2008;29:138. [PubMed: 18599325]

9. Reinhardt RL, Liang HE, Locksley RM. Nat. Immunol 2009;10:385. [PubMed: 19252490]

10. Ansel KM, McHeyzer-Williams LJ, Ngo VN, McHeyzer-Williams MG, Cyster JG. J. Exp. Med 1999;190:1123. [PubMed: 10523610]

11. Ansel KM, et al. Nature 2000;406:309. [PubMed: 10917533]

12. Hardtke S, Ohl L, Förster R. Blood 2005;106:1924. [PubMed: 15899919]

13. Fazilleau N, McHeyzer-Williams LJ, Rosen H, McHeyzer-Williams MG. Nat. Immunol 2009;10:375. [PubMed: 19252493]

14. Ye BH, et al. Nat. Genet 1997;16:161. [PubMed: 9171827]

15. Dent AL, Shaffer AL, Yu X, Allman D, Staudt LM. Science 1997;276:589. [PubMed: 9110977]

16. Klein U, Dalla-Favera R. Nat. Rev. Immunol 2008;8:22. [PubMed: 18097447]

17. Martins G, Calame K. Annu. Rev. Immunol 2008;26:133. [PubMed: 18370921]

18. Cimmino L, et al. J. Immunol 2008;181:2338. [PubMed: 18684923]

19. Shaffer AL, et al. Immunity 2002;17:51. [PubMed: 12150891]

20. Shaffer AL, et al. Immunity 2000;13:199. [PubMed: 10981963]

21. Cattoretti G, et al. Blood 1995;86:45. [PubMed: 7795255]

22. Vinuesa CG, Tangye S, Moser B, Mackay C. Nat. Rev. Immunol 2005;5:853. [PubMed: 16261173]

23. Akiba H, et al. J. Immunol 2005;175:2340. [PubMed: 16081804]

24. Reljic R, Wagner SD, Peakman LJ, Fearon DT. J. Exp. Med 2000;192:1841. [PubMed: 11120780]

25. Martins GA, Cimmino L, Liao J, Magnusdottir E, Calame K. J. Exp. Med 2008;205:1959. [PubMed: 18725523]

26. Gong D, Malek TR. J. Immunol 2007;178:242. [PubMed: 17182561]

27. Crotty S, Kersh EN, Cannons J, Schwartzberg PL, Ahmed R. Nature 2003;421:282. [PubMed: 12529646]

28. Ma CS, Nichols KE, Tangye S. Annu. Rev. Immunol 2007;25:337. [PubMed: 17201683]

29. Schwartzberg PL, Mueller KL, Qi H, Cannons JL. Nat. Rev. Immunol 2009;9:39. [PubMed: 19079134]

30. Kallies A, et al. Nat. Immunol 2006;7:466. [PubMed: 16565720] 
31. Martins GA, et al. Nat. Immunol 2006;7:457. [PubMed: 16565721]

32. Shapiro-Shelef M, et al. Immunity 2003;19:607. [PubMed: 14563324]

33. Tsiagbe, VK.; Thorbecke, GJ. The Biology of Germinal Centers. Thorbecke, GJ.; Tsiagbe, VK., editors. Springer-Verlag; Berlin: 1998. p. 1-103.

34. Kopf M, Le Gros G, Coyle AJ, Kosco-Vilbois M, Brombacher F. Immunol. Rev 1995;148:45. [PubMed: 8825282]

35. King IL, Mohrs M. J. Exp. Med 2009;206:1001. [PubMed: 19380638]

36. Zaretsky AG, et al. J. Exp. Med 2009;206:991. [PubMed: 19380637]

37. Hsu HC, et al. Nat. Immunol 2008;9:166. [PubMed: 18157131]

38. Smith KM, Brewer JM, Rush CM, Riley J, Garside P. J. Immunol 2004;173:1640. [PubMed: 15265892]

39. Smith KM, et al. J. Immunol 2000;165:3136. [PubMed: 10975827]

40. We thank R. Kageyama, L. Crickard, K. Hansen, C. Kim, and K. Van Gunst for technical assistance; S. Kaech for helpful discussions; A. Haberman and S. Kerfoot for technical help; and the NIH Tetramer Core for providing MHC class II tetramer reagents. Supported by LIAI institutional funds, a Pew Scholar Award, a Cancer Research Institute Award, and National Institute of Allergy and Infectious Diseases grants R01 072543 and NIAID R01 063107 (S.C.); Rheuminations Inc., the Arthritis Foundation, the Connecticut Chapter of the Lupus Foundation of America, and NIH grants AR40072, AR44076, and P30 AR053495 (J.C.); and fellowships from the UCSD/LIAI Immunology NIH Training Grant (I.Y. and R.J.J.). R.J.J. is a member of the UCSD Biomedical Sciences (BMS) graduate program. Microarray data have been deposited at the NCBI Gene Expression Omnibus (GSE16697). Author contributions are as follows: LCMV $\mathrm{T}_{\mathrm{FH}}$ identification and microarrays, I.Y. and S.C.; Bcl6-RV and Blimp1-RV experiments, R.J.J., D.D., B.B.; $\mathrm{T}_{\mathrm{FH}}$ migration, D.E.; Blimp-1 conditional knockout experiments, D.D.; Bcl6 ${ }^{-/-}$mice, A.L.D.; Bcl6 ${ }^{-/-}$experiments, A.C.P.; writing, S.C. (with intellectual and editorial contributions from the other authors); project conception and experimental design, S.C. and J.C. 


\section{A}

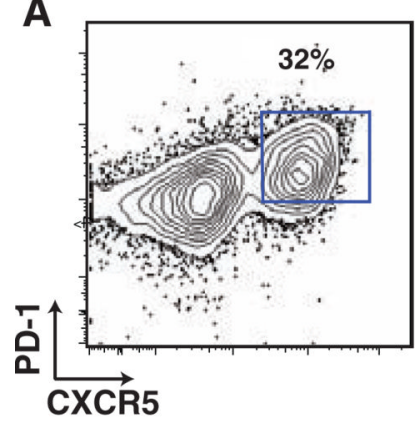

C

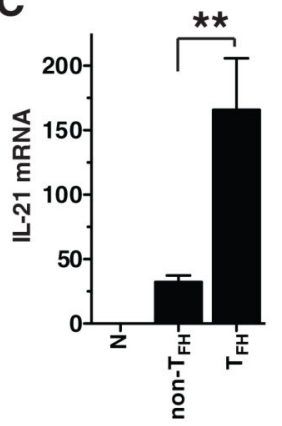

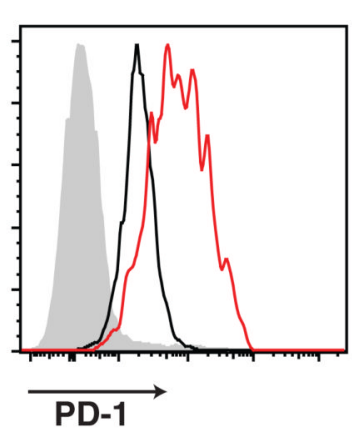

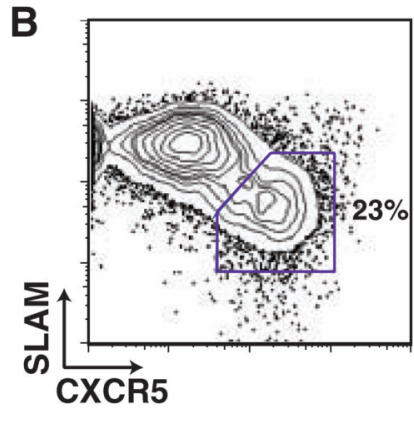

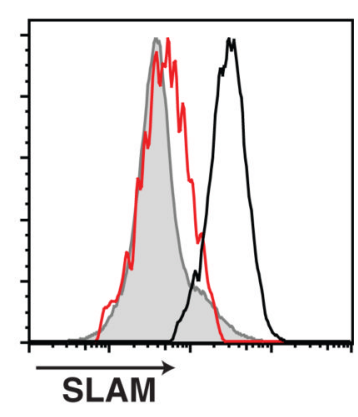

E
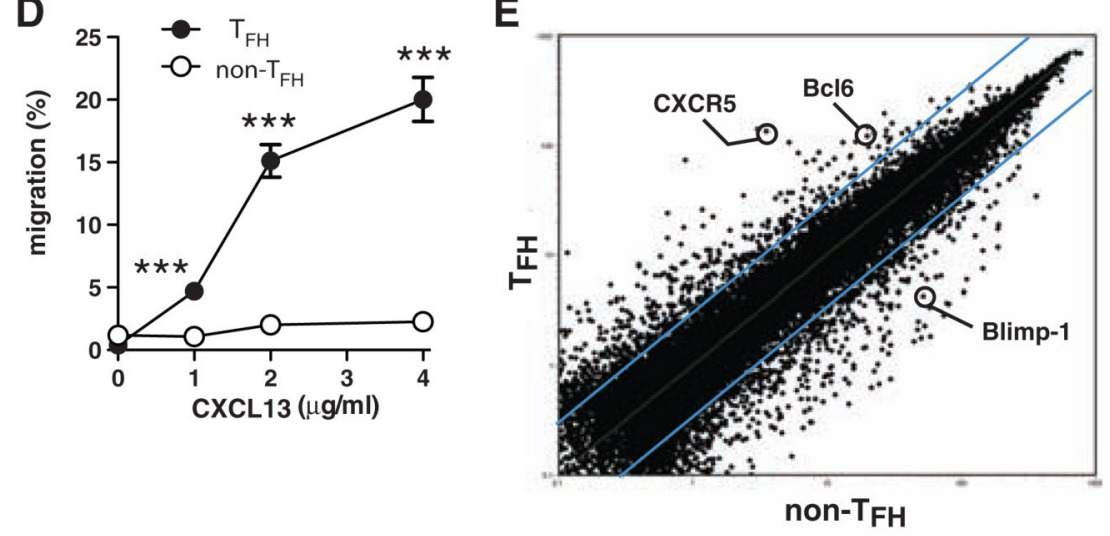

F

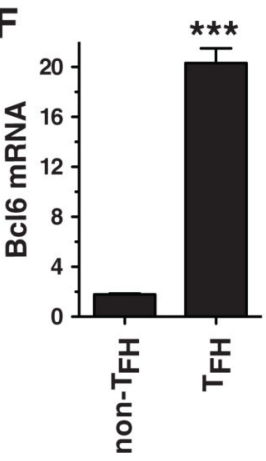

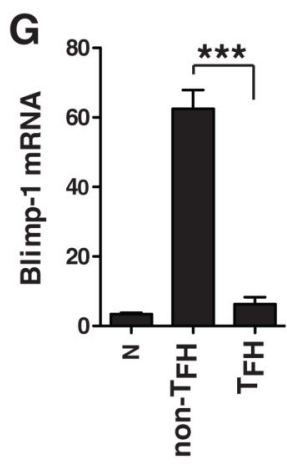

Fig. 1.

Bcl6 is a $\mathrm{T}_{\mathrm{FH}^{-} \text {-specific transcription factor. Naïve SMtg CD4 }}{ }^{+} \mathrm{T}$ cells were transferred into B6 mice. In all panels, splenocytes were analyzed 8 days after infection with LCMV. (A and B) SMtg expression of CXCR5 and PD-1 (A) or SLAM (CD150) (B). SMtg ${ }^{+}\left(\mathrm{CD} 45.1^{+}\right) \mathrm{CD}^{+}$ gated cells are shown. CXCR5 $5^{\text {high }} \mathrm{T}_{\mathrm{FH}}$ cells are boxed in fluorescence-activated cell sorter (FACS) plots. Histogram overlays depict $\mathrm{T}_{\mathrm{FH}}$ cells (red) as well as naïve $\mathrm{CD}^{+}{ }^{+} \mathrm{T}$ cells (gray) and $\mathrm{CXCR}^{\text {low }}$ non- $\mathrm{T}_{\mathrm{FH}} \mathrm{SMtg}$ cells (black). Data are representative of more than 10

independent experiments. (C) IL-21 mRNA in SMtg CD4 ${ }^{+}$T cells, normalized to the $\beta$-actin mRNA level $\left(\times 10^{-4}\right) * * P=0.008$. (D) In vitro chemotaxis toward CXCL13 (BLC) by ex vivo SMtg CD4 ${ }^{+}$T cells. Results are expressed as percentages of SLAM ${ }^{\text {low }} \mathrm{T}_{\mathrm{FH}}$ SMtg (solid circles) and SLAM ${ }^{\text {high }}$ non- $\mathrm{T}_{\mathrm{FH}}$ SMtg (open circles) that migrated in a transwell assay. $* * * P \leq 0.001$. $1 \mu \mathrm{g}, P=0.001 ; 2 \mu \mathrm{g}, P=0.0006 ; 4 \mu \mathrm{g}, P=0.0006$. Data are representative of three independent experiments; $n=2$ per group. (E) Scatterplot of the average signal of biological replicates of $\mathrm{T}_{\mathrm{FH}}$ versus non- $\mathrm{T}_{\mathrm{FH}} \mathrm{SMtg}$ gene expression microarray data. Blue lines indicate changes in gene expression by a factor of $3 ; 386$ gene probes exhibited a factor of $>3.0$ increase in $\mathrm{T}_{\mathrm{FH}}$. 
Data from one of two independent experiments are shown; $n=2$ per group. (F and $\mathbf{G}$ ) Quantitative reverse transcription PCR of Bcl6 (F) and Blimp-1 (G) mRNA expression, normalized to $\beta$-actin $\left(\times 10^{-4}\right)$. $* * * P<0.0001$. Data are representative of four independent experiments; $n=2$ per group. Error bars in all graphs are SEM. 
A

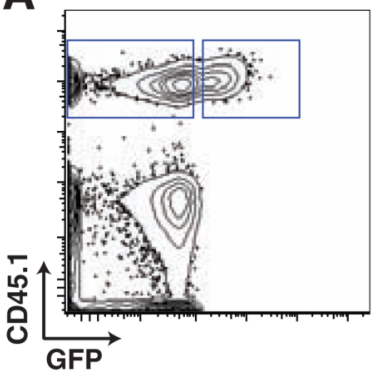

B

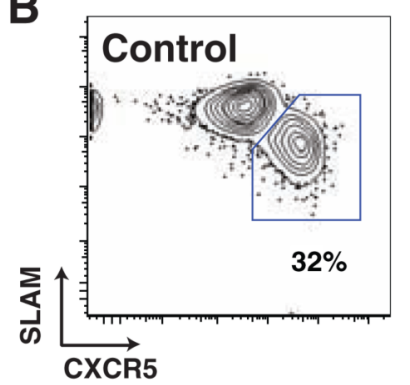

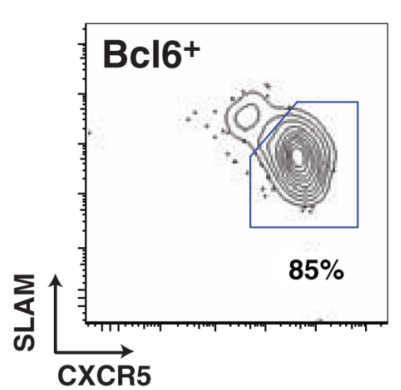

C
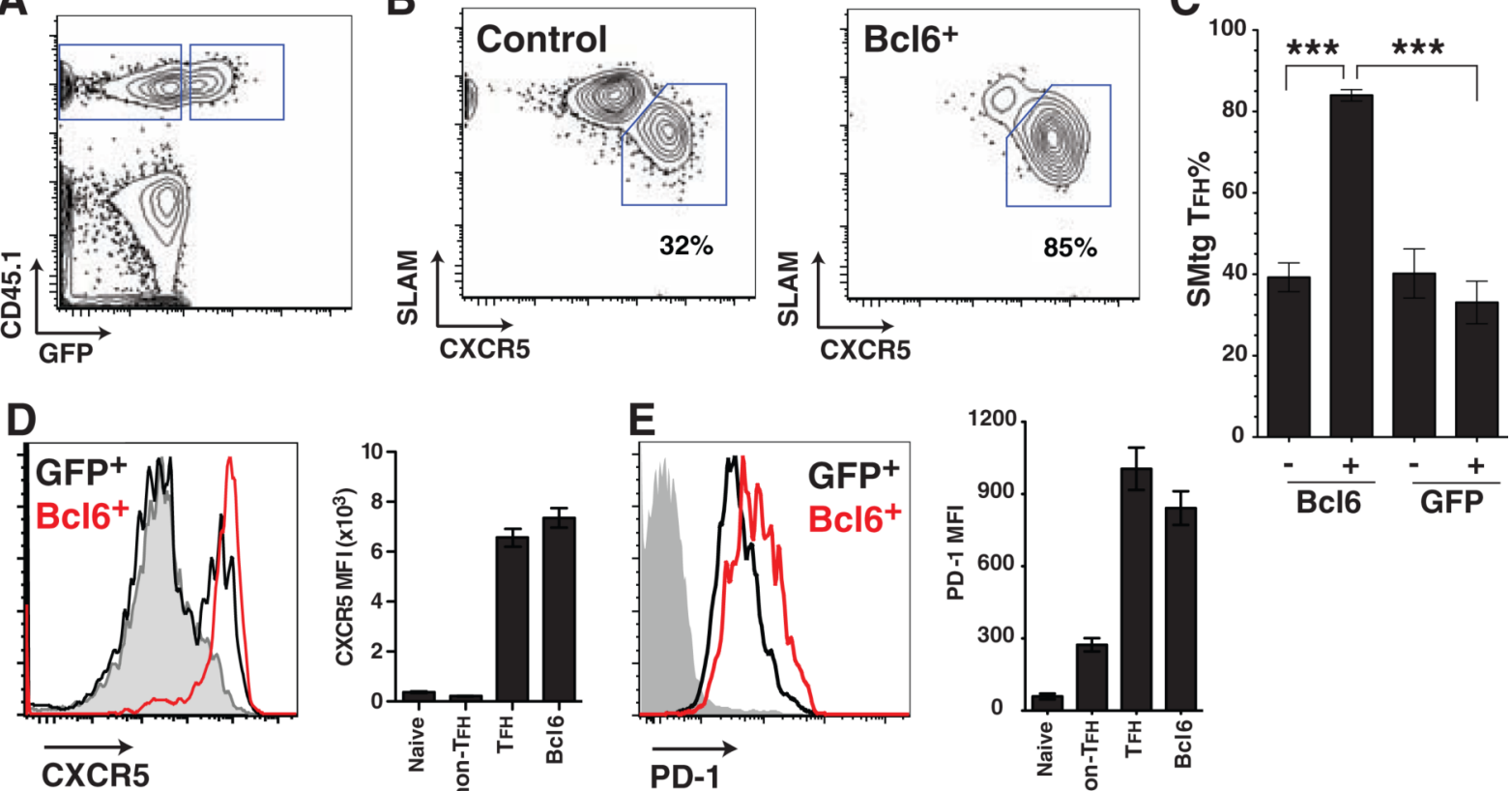
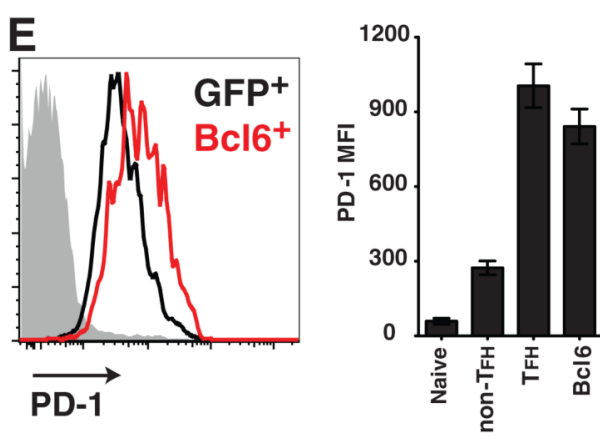

$\mathbf{F}$

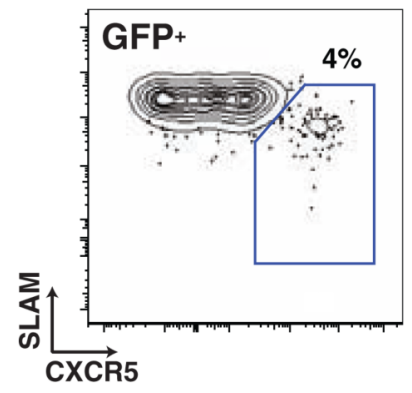

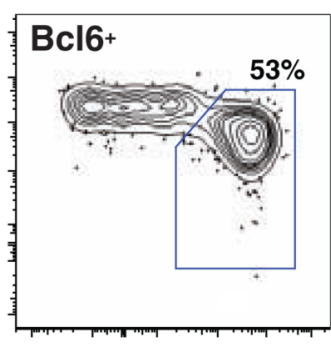

G

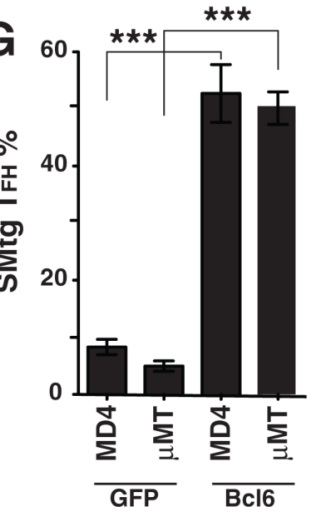

Fig. 2.

Bcl6 expression is sufficient for $\mathrm{T}_{\mathrm{FH}}$ differentiation in vivo. (A to $\mathbf{E}$ ) Naïve SMtg CD4 ${ }^{+} \mathrm{T}^{-}$cells were transduced with Bcl6-RV $\left(\mathrm{Bcl6}^{+}\right)$or left untransduced (control) and transferred into B6 mice subsequently infected with LCMV. (A) Gating of CD45.1 $1^{+}$untransduced SMtg $\left(\mathrm{GFP}^{-}\right.$) and Bcl6- $\mathrm{RV}^{+} \mathrm{SMtg}\left(\mathrm{GFP}^{+}\right)$in the same host. $\mathrm{CD}^{+} \mathrm{B} 220^{-}$gate is shown. (B) $\mathrm{T}_{\mathrm{FH}}$ (SLAM $^{\text {low }}$ CXCR5 $^{\text {high }}$, boxed) and non- $\mathrm{T}_{\mathrm{FH}}\left(\mathrm{SLAM}^{\text {high }} \mathrm{CXCR}^{\text {low }}\right)$ differentiation of untransduced SMtg (left) and Bcl6-RV ${ }^{+}$SMtg (right). (C) Quantitation of SMtg $\mathrm{T}_{\mathrm{FH}}$ differentiation. Mice received Bcl6- $\mathrm{RV}^{+} \mathrm{SMtg}$ and untransduced SMtg, or GFP-RV ${ }^{+}$and untransduced SMtg. “-," untransduced; “+," transduced with indicated RV. ***P $<0.0001$. Data are representative of three independent experiments; $n=4$ per group. (D and E) CXCR5 expression (D) and PD-1 expression (E) on naïve CD4 ${ }^{+}$T cells (gray), GFP-RV ${ }^{+}$SMtg (black), and Bcl6-RV ${ }^{+} \mathrm{SMtg}$ (red). Bar graphs show mean fluorescence intensity (MFI) of naïve $\mathrm{CD}^{+}{ }^{+} \mathrm{T}$ cells, GFP-RV ${ }^{+}$SMtg non- $\mathrm{T}_{\mathrm{FH}}$, GFP-RV ${ }^{+} \mathrm{SMtg}_{\mathrm{FH}}$, and Bcl6-RV ${ }^{+}$SMtg. For PD-1 $\mathrm{MFI}$, non- $\mathrm{T}_{\mathrm{FH}}$ versus $\mathrm{T}_{\mathrm{FH}}$ or $\mathrm{Bcl}-\mathrm{RV}^{+}, P<0.05 ; \mathrm{T}_{\mathrm{FH}}$ versus $\mathrm{Bcl6}-\mathrm{RV}^{+}, P>0.05$. Data are representative of three independent experiments; $n=4$ to 6 per group. (F and $\mathbf{G}) \mathrm{GFP}^{-\mathrm{RV}^{+} \text {or }}$ Bcl6-RV ${ }^{+}$SMtg cells were adoptively transferred separately into B cell-deficient mice $(\mu \mathrm{MT})$ or HEL-specific BCR transgenic mice (MD4) on a $\mu \mathrm{MT}$ background. Host mice were subsequently infected with LCMV. Each group is a composite of three experiments; $n=2$ (GFP-RV $\left.{ }^{+} \mu \mathrm{MT}\right), 6$ (Bcl6-RV $\left.{ }^{+} \mathrm{MD} 4\right), 6\left(\mathrm{Bcl6}_{-} \mathrm{RV}^{+} \mu \mathrm{MT}\right)$, or 8 (GFP-RV $\left.{ }^{+} \mathrm{MD} 4\right)$ per group. 
(F) Differentiation of SMtg CD4 ${ }^{+} \mathrm{T}$ cells in MD4 BCR transgenic mice. $\mathrm{T}_{\mathrm{FH}}$ cells (SLAM ${ }^{\text {low }} \mathrm{CXCR}^{\text {high }}$ ) are boxed. $\mathrm{CD}^{+}{ }^{+} \mathrm{B} 220^{-} \mathrm{CD} 45.1^{+} \mathrm{GFP}^{+}$gate is shown. $(\mathrm{G})$

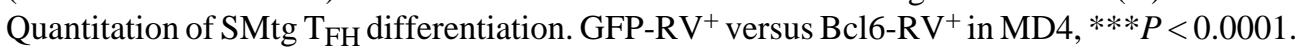
GFP-RV ${ }^{+}$versus Bcl6- $\mathrm{RV}^{+}$in $\mu \mathrm{MT}$, $* * * P<0.0001$. 
A
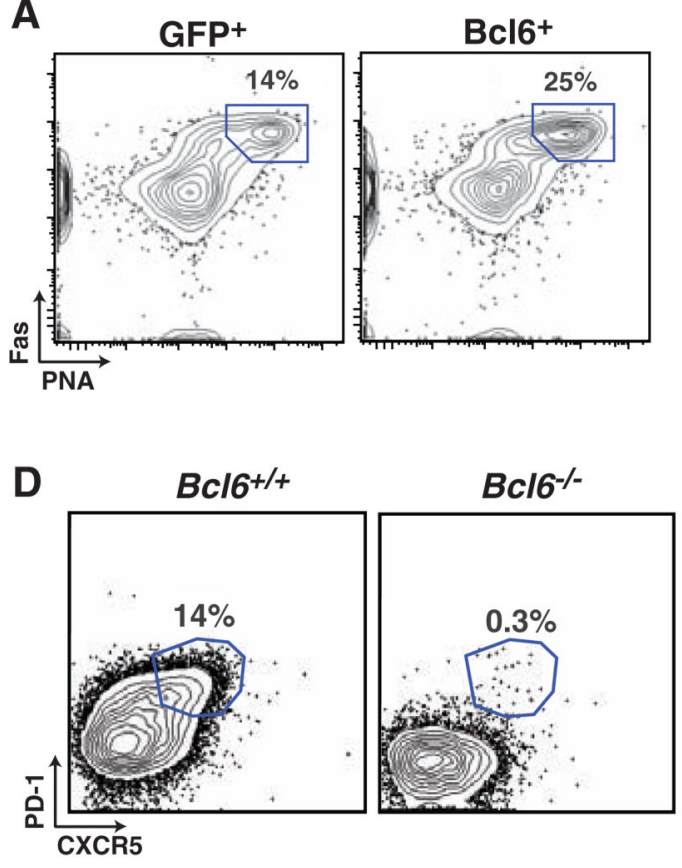

B
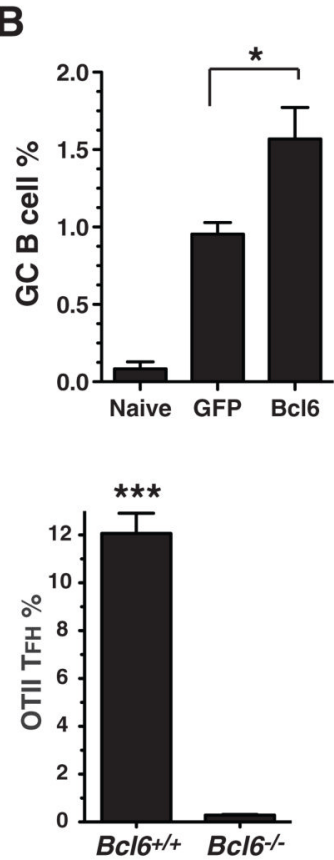

C

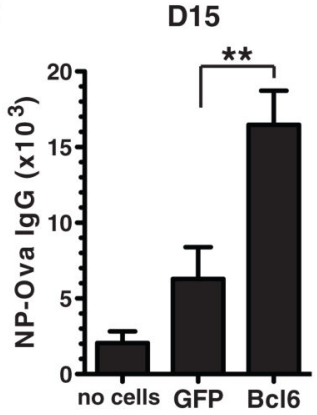

E

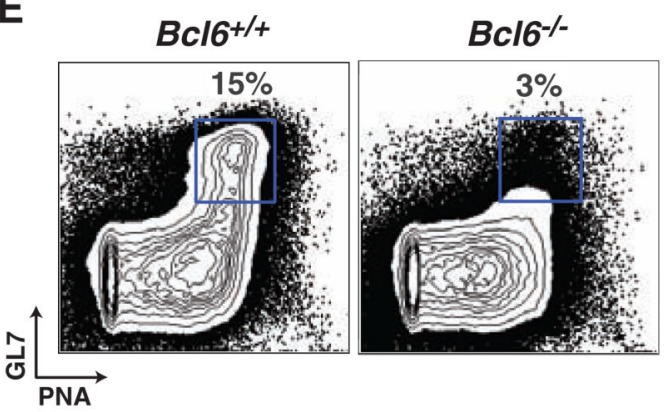

F

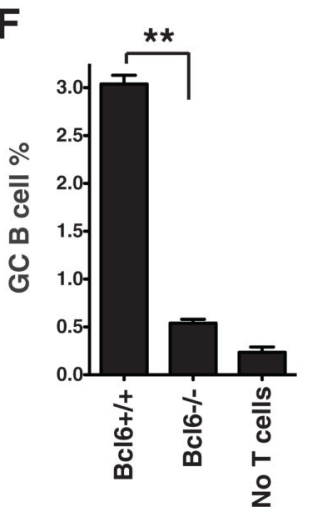

G

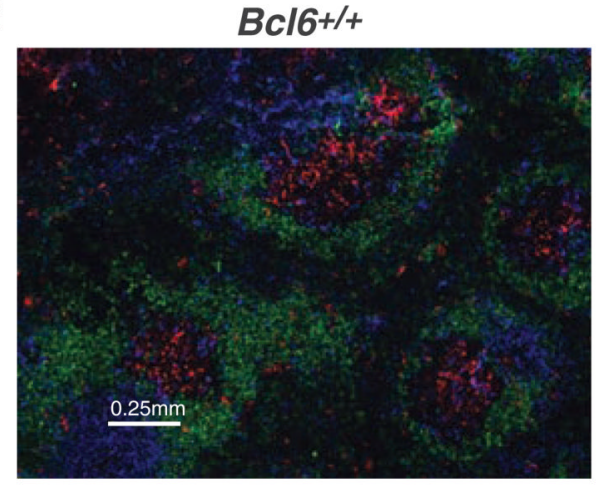

$B \mathrm{cl} 6 \%$

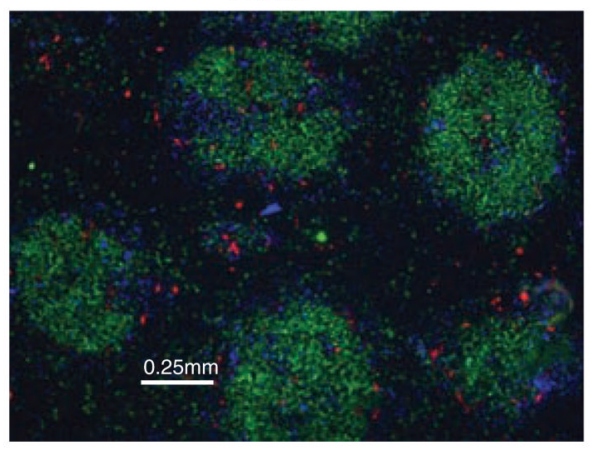

Fig. 3.

Bcl6 expression is necessary for inducing $\mathrm{T}_{\mathrm{FH}} \mathrm{B}$ cell help in vivo. (A) Germinal center $\mathrm{B}$ cells $\left(\mathrm{PNA}^{+} \mathrm{Fas}^{+}\right.$, gated) in mice that received GFP-RV ${ }^{+}$or Bcl6- $\mathrm{RV}^{+} \mathrm{SMtg} \mathrm{CD}^{+} \mathrm{T}$ cells and were subsequently infected with LCMV, analyzed at day 8 and gated on activated B cells (B220 ${ }^{+}$ $\left.\mathrm{IgD}^{\text {low }}\right)$. (B) Frequency of germinal center B cells of total splenocytes; $n=4$ per group. Data are representative of three independent experiments. ${ }^{*} P=0.029$. (C) GFP-RV ${ }^{+}$or $\mathrm{Bcl6}-\mathrm{RV}^{+}$ $\mathrm{OT}_{-1 I} \mathrm{CD}^{+}{ }^{+} \mathrm{T}$ cells were transferred into B6 mice subsequently immunized with NP-Ova in alum. Control mice were immunized but received no OT-II cells. NP-Ova enzyme-linked immunosorbent assay (ELISA) was performed at day 15 and day $45 ; n=6$ per group. Data are representative of two independent experiments. Day 15 endpoint ELISA titers, $* * P=0.008$; day 45 endpoint ELISA titers, ${ }^{*} P=0.017$.(D) $\mathrm{Bcl6}^{+/+}$or $\mathrm{Bcl6}^{-/-}$OT-II CD4 ${ }^{+}$Tcells were transferred into congenically mismatched B6 mice subsequently immunized with Ova in alum. Splenocytes were analyzed 6 days after immunization; $n=4$ per group. Data are representative of four independent experiments. OT-II ${ }^{+} \mathrm{CD} 44^{\text {high }}$ gate is shown. Quantitation of OT-II T $\mathrm{FH}$ differentiation is also shown. $* * * P<0.0001$. (E to $\mathbf{G}) \mathrm{Bcl6}^{+/+}$or $\mathrm{Bcl}^{-/-}$OT-II CD4 ${ }^{+} \mathrm{T}$ cells

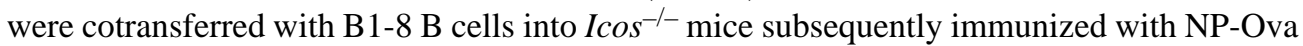
in alum; $n=2$ per group. Data are representative of two independent experiments. (E) Germinal 
center B cells $\left(\mathrm{PNA}^{+} \mathrm{GL}^{+}\right.$, boxed) 7 days after immunization. TCR $\beta^{-} \mathrm{IgD}^{\text {low }}$ gate is shown. (F) Quantitation of GC B cells as percent of spleen. $* * P=0.0015$. (G) Germinal center histology. Spleen sections were stained with IgD (green), PNA (red), and CD4 (blue). 

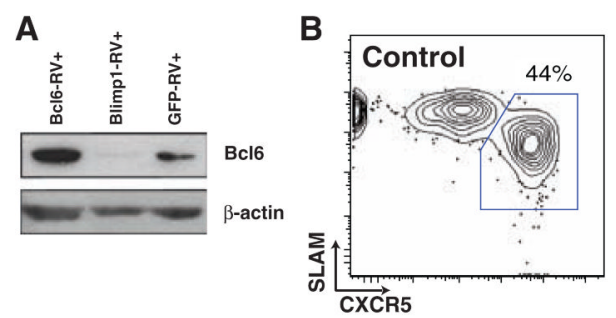

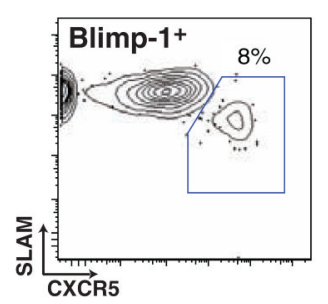

E

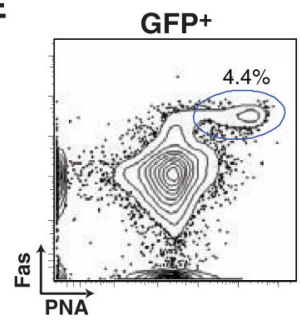

G

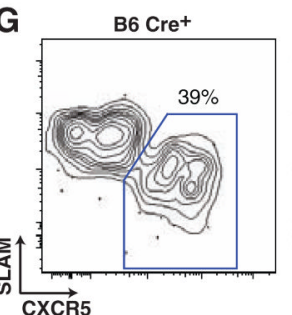

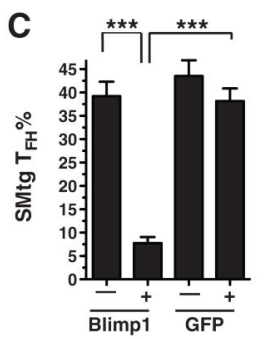
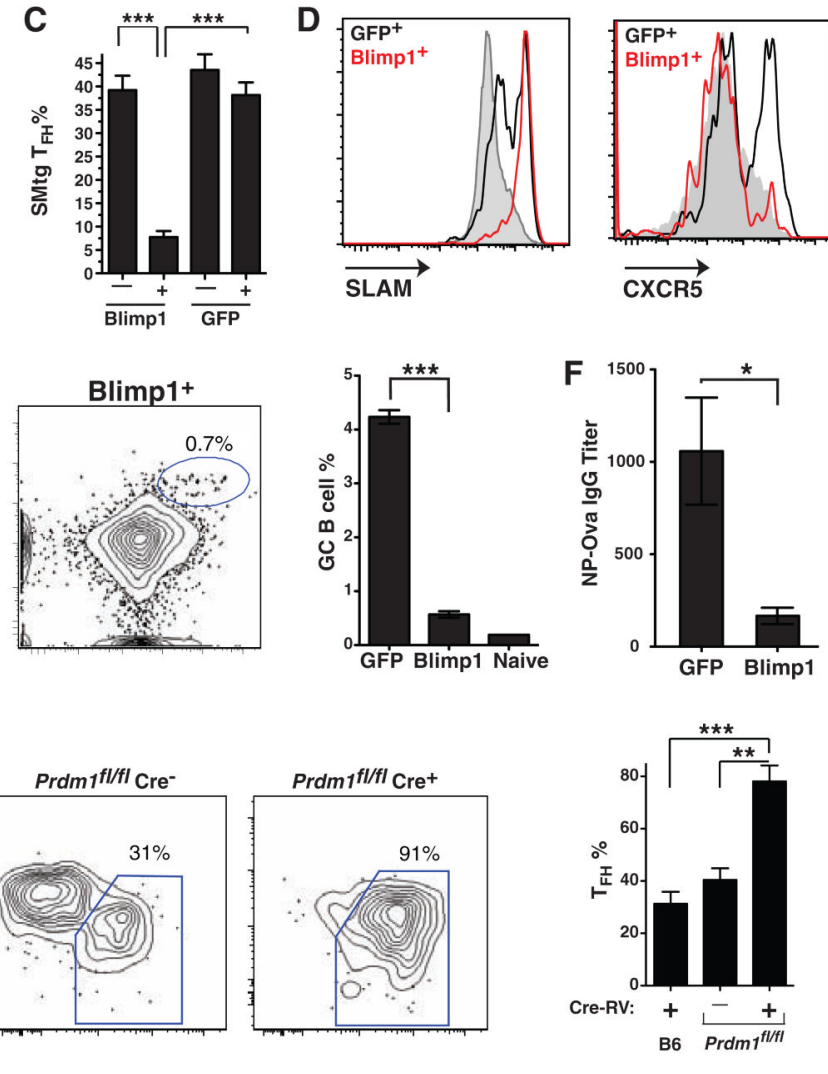
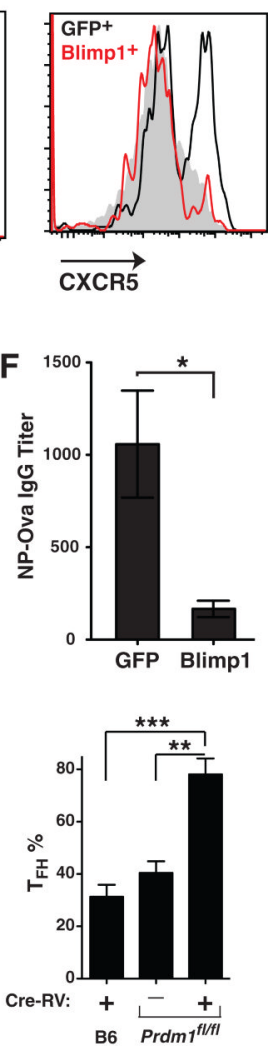

Fig. 4.

Blimp-1 and Bcl6 are antagonistic and reciprocal regulators of $\mathrm{T}_{\mathrm{FH}}$ differentiation. (A) Immunoblot of Bcl6 protein expression (and $\beta$-actin control) in transduced SMtg $\mathrm{CD} 4^{+} \mathrm{T}$ cells in vivo. (B) $\mathrm{T}_{\mathrm{FH}}$ (SLAM ${ }^{\text {low }}$ CXCR5 ${ }^{\text {high }}$, boxed) differentiation of untransduced SMtg (left, "Control") and Blimp1-RV ${ }^{+}$SMtg (right, "Blimp-1"”) cells within a common host 8 days after LCMV infection. Gating is shown in fig. S10B. (C) Quantitation of SMtg $\mathrm{T}_{\mathrm{FH}}$ differentiation. “-," untransduced; “+," transduced with the indicated RV. *** $P<0.0001 ; n=4$ per group. Data are representative of two independent experiments. (D) SLAM and CXCR5 expression by naïve $\mathrm{CD} 4^{+} \mathrm{T}$ cells (gray), GFP-RV ${ }^{+} \mathrm{SMtg}$ (black), and Blimp1-RV ${ }^{+} \mathrm{SMtg}$ (red). (E and F) $\mathrm{GFP}_{-\mathrm{RV}}{ }^{+}$or Blimp1-RV ${ }^{+} \mathrm{OT}-\mathrm{II} \mathrm{CD} 4^{+} \mathrm{T}$ cells were transferred into SAP-deficient mice subsequently immunized with NP-Ova in alum; $n=4$ per group. Data are representative of three independent experiments. (E) Germinal center B cells $\left(\mathrm{PNA}^{+} \mathrm{Fas}^{+}\right.$, gated) in mice that received GFP- $\mathrm{RV}^{+}$or Blimp1-RV $\mathrm{RV}^{+} \mathrm{OT}-\mathrm{II} \mathrm{CD}^{+} \mathrm{T}$ cells. $\mathrm{B} 220^{+} \mathrm{IgD}^{\text {low }}$ gate is shown. Quantitation of germinal center B cells in the spleen is also shown. $* * * P<0.0001$. (F) NPOva IgG ELISA endpoint titers at day $10 . * P=0.016$. (G) Purified naïve B6 and prdm $1^{f l / f l}$ $\mathrm{CD} 45.2^{+} \mathrm{CD}^{+} \mathrm{T}$ cells were transduced with SMtg-RV, with or without Cre-RV $\left(\mathrm{Cre}^{+}\right.$or $\mathrm{Cre}^{-}$), sorted, and transferred into CD45.1 $1^{+}$mice subsequently infected with LCMV. FACS plots depict $\mathrm{T}_{\mathrm{FH}}$ (CXCR5 ${ }^{\text {high }} \mathrm{SLAM}^{\text {low }}$, boxed) differentiation of control $\mathrm{Cre}^{+} \mathrm{SMtg}^{+} \mathrm{B} 6$ cells (left), Blimp-1-sufficient $\mathrm{Cre}^{-} \mathrm{SMtg}^{+}$prdm $1^{f l / f l}$ cells (center), and Blimp-1-deficient $\mathrm{Cre}^{+}$ $\mathrm{SMtg}^{+}$prdm $1^{f l f l}$ cells (right). $\mathrm{CD} 4^{+} \mathrm{CD} 45.1^{-} \mathrm{CD} 44^{\text {high }} 7 \mathrm{AAD}^{-}$gate is shown. Quantitation of $\mathrm{T}_{\mathrm{FH}}$ differentiation is also shown. Data are representative of two independent experiments. ** $P=0.002, * * * P=0.0006 ; n=4$ to 5 per group. 